\title{
УТИЦАЈ ГЛОБАЛИЗАЦИЈЕ НА КОМУНИКАТИВНИ ДИСКУРС ЧЕСТИТАњА**
}

\begin{abstract}
У раду се анализирају статус и промена форми честитања у писаној реализацији, као и основне карактеристике организације текста и синтаксичке типске одлике честитки послатих путем нових медија. На корпусу који укључује новогодишње и божићне честитке послате у форми СМС порука показује се да је у последњој деценији битно измењен начин честитања. Те измене односе се на различите аспекте, почев од односа између пошиљаоца и примаоца поруке, који постаје много мање личан и директан. На плану саме организације текста јасно се диференцирају дуже поруке које су најчешће циркуларне, намењене великом броју прималаца, и оне сасвим кратке које су добиле стереотипну форму. Језички код често је комбинован са сликовним елементима, док синтаксичка организација показује високу шаблонизованост.
\end{abstract}

Кључне речи: СМС-поруке, честитање, деперсонализација, пошиљалац, прималац

\section{1. Уводне напомене}

Предмет овога рада јесте промена саме форме честитања у писаној реализацији, као и анализа основних текстуалних и синтаксичких карактеристика честитки послатих путем CMC-порука.

Корпус укључује око 100 божићних и новогодишњих честитки. ${ }^{1}$ Међу порукама се издвајају два основна типа: поруке које су писане као честитке које су се слале поштом и поруке које имају потпуно нова обележја. Првих

*ilijana.cutura@gmail.com

** Рад је настао у оквиру пројекта 178014 Динамика структура савременог српског језика, који финансира Министарство просвете, науке и технолошког развоја Републике Србије.

1 За прикупљање материјала и формирање корпуса велику захвалност дугујем Милени Марковић, студенту Факултета педагошких наука у Јагодини. Укључивање студента у ову фазу рада омогућило је да располажем и честиткама које су намењене млађој популацији. 
је знатно мање, док је други тип далеко фреквентнији. Једна од основних карактеристика другог типа СМС-честитки јесте да су циркуларне, односно да омогућују честитање великом броју прималаца. Додатно, истом поруком празнике честита велики број пошиљалаца који нису и аутори честитке. Тако се у комуникационом ланцу појављује још најмање један актер - креатор поруке који је, највероватније, пошиљалац у првом кругу слања, тако да сви следећи пошиљаоци (који преузимају готову честитку и прослеђују је) нису и енкодери. ${ }^{2}$

1.1. Честитање, као једна од конвенција учтивости, спада у говорне чинове који се односе на саговорника (Мразовић 2009: 675) и у усменој реализацији углавном је праћено невербалним комуникационим средствима (стисак руке, загрљај, пољубац и сл.). Посебно се честитке упућене поводом верских празника карактеришу употребом уобичајених израза (нпр. Христос се роди! - Ваистину се роди!), с тим што „припадници осталих вјера и атеисти честитају све ове празнике само са: Срећан Божић! Срећан Васкрс!” (Шипка 2008: 226). „Изузетно, кад се жели исказати посебно поштовање и солидарност, и они којима то није празник обраћају се вјерницима ријечима и изразима који се употребљавају унутар њихове вјерске заједнице” (Исто: 226).

Иако у стручној литератури код нас није много писано о језичким и стилским карактеристикама честитања, можемо рећи да је општеприхваћен став да су честитке у језичком погледу кратки текстови усмерени на примаоца поруке, те да имају одређене чврсте обрасце и језичке шаблоне (в. Ристић 1999, Бабић 2010, Шипка 2008, Тошовић 2002). Међутим, комуницирање посредством нових медија (интернета и мобилних телефона пре свега) битно мења сам карактер комуникације, па и њено језичко обликовање.

1.2. Кристал (2001: 263-264) наводи да се СМС-сервис ${ }^{3}$ развио деведесетих година XX века и да је овај начин комуникације доживео брзу експанзију. У свету је само у 2004. години послато око 500 милијарди оваквих порука, а приметно је да се просечни узраст корисника мобилних телефона смањује, тако да, према Кристалу, чак две трећине деце између 14 и 16 година, на светском нивоу, има свој мобилни телефон, а корисници од само 10-11 година представљају потрошаче чији број најбрже расте. Основни циљеви комуникације кратким порукама, подржане и сервисима посредованим интернетом, код младих (15-25 година) јесте координисање сопственог друштвеног живота, „поигравање језиком” и исказивање наклоности према другим особама (код чак $37 \%$ свих пошиљалаца СМС-порука, према: Кристал 2001: 264). Честитање свакако спада у овај тип мотива употребе текстуалних порука, те се у овом смислу сам чин честитања и медиј комуницирања узајамно подржавају.

1.3. Оно што свакако остаје као теоријски проблем јесте питање да ли су СМС-поруке ближе писаном или говорном језику, или је најбоље решење

2 У дискусији на скупу проф. Оливера Дурбаба навела је да, према новинарским истраживањима, постоји могућност да су креатори једног броја оваквих честитки саме компаније које се баве пружањем услуга мобилне телефоније, те да на овај начин обезбеђују велики профит.

${ }^{3} \mathrm{CMC}$ је скраћеница за синтагму short message service (,услуга кратких порука”). 
да се језик СМС-порука посматра као нека врста хибрида. Он показује неке стандардне карактеристике (Кристал 2008, Сегештад 2005) - на пример, емотиконе или скраћенице - од којих наш корпус, због специфичности чина честитања, у великој мери одступа. Вероватно због тога у нашем корпусу нема ни англицизама који су редовно обележје комуникације посредством савремених медија у данашње време (упор. Ашић 2014: 85-97; Јањић/Чутура 2012), али и обележје савременог српског језика уопште (в. Јањић 2014, Прћић 2011).

\section{2. Организација текста и језичке карактеристике СМС-честитки}

Доминантне карактеристике СМС-честитки, које директно проистичу из природе средства (канала) комуникације, јесу деперсонализација и економичност. Иако се виртуелним заједницама, каква је и скуп особа у телефонском именику, чет група и слично, приписује својеврсна романтика еквивалентна „носталгији за градићем у коме се људи познају, помажу једни другима и деле добро и зло које им живот доноси, а комуникација у виртуелним заједницима замењује све те функције традиционалне заједнице” (Радић-Бојанић 2007: 61), поруке које се шаљу за Божић и Нову годину су углавном формулисане тако да су намењене свима, већином немају конкретног примаоца, већ се могу послати свим особама из телефонског именика, без обзира на то колико смо заиста блиски са онима којима честитку шаљемо.

2.1. У порукама се због тога не појављује име ни пошиљаоца ни примаоца поруке, нити има било каквог упућивања на личност. Мали број порука је такав да је намењен конкретној особи, са конкретним жељама које се везане за ту особу. У највећем броју оваквих честитки упућене жеље су формулисане довољно уопштено да би могле бити примењене на велики број прималаца без обзира на пол, породични статус, године и сл. Пошиљалац у највећем броју случајева жели срећу, мир и љубав или одређеном дозом хумора обезбеђује универзалност честитке, као у следећим примерима:

Док се мучиш с' посним ослићем, нешто лијепо миришеш носићем. То се у рерни прасенце пече, добри доме, СРЕЋНО БАДњЕ ВЕЧЕ

Moram ti ovo priznati, mada je glupo što je preko poruke, ali ja nemam hrabrosti da ti kažem u lice, znam da ti se ovo neće svideti, veruj nije ni meni lako, ali moraćeš da saznaš istinu kad tad a i bolje da to čuješ od mene nego od nekog drugog... PRAVI DEDA MRAZ NE POSTOJI! Ipak, ja ti mogu doneti SRECU...

Веома су ретке поруке у којима пошиљалац јасно идентификује примаоца/примаоце, било властитим именом или конкретизацијом упућене жеље, као у наредном примеру:

\footnotetext{
${ }^{4}$ Све поруке преносимо у оригиналу, без корекције правописних и граматичких грешака.
} 


\section{СРЕЋАН БОЖИЋ! ПУНО СРЕЋЕ, ПУНО ЗДРАВЉА И ВЕСЕЉА, ДА СЕ УДАЈЕТЕ И ДА СЛАВИТЕ СЛАВУ КАКО ДОЛИКУЈЕ! СРЕЋАН БОЖИЋ! \\ Срећан вам Бадњи Дан и Божић Марковићи!}

Želim ti ono što se niko nikada nije setio da ti poželi, a što iščekuješ ćutanjem. Neka i to, neizrecivo, što samo ti znaš bude ispunjeno! Srećna Nova koleginice draga.

На пошиљаоца и примаоца упућује се најчешће само глаголским или заменичким лицем:

U najlepšoj Srpskoj noći, moj će pozdrav tebi doći...

Šta da ti poklonim za Novu Godinu? Auto, novac, prijateljstvo? Za prve dve želje obrati se Deda Mrazu, a prijateljstvo ću $t i$ pokloniti $J A$ !

Tom Kruz, Anđelina Žoli, Madona, Arnold Švarceneger, Dženifer Lopez, Džordž Kluni i $j a \ldots$ Sve velike svetske zvezde $t i$ žele SREĆNU NOVU GODINU.

Најчешћи начин упућивања на пошиљаоца је искључиво лице у којем је глагол у личном глаголском облику. Међутим, веома високу шаблонизованост ових језичких образаца показује чињеница да се у највећем броју случајева ради о презенту глагола желети и то готово увек у првом лицу једнине. Ово није карактеристика утицаја нових медија с обзиром на то да је овај глагол иначе најчешће део обавезне форме честитања.

Употреба првог лица множине, која је знатно ређа, често се своди на „опште” прво лице множине које обухвата широку (друштвену, националну и/или верску) заједницу:

U najlepšoj Srpskoj noći, moj će pozdrav tebi doći, puno sreće zdravlja i veselja od iskrenog prijatelja! S čašom vina i nazdravlje živelo nam pravoslavlje!

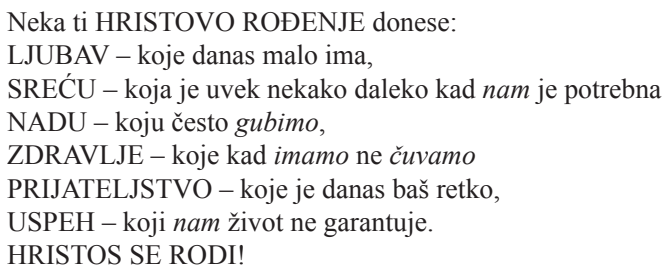

Нешто ређе се појављује и пошиљалац (углавном као реченични субјекат), означен углавном заменицом 1. лица једнине, и то или употребом личне или употребом присвојне заменице (типа моје жеље).

Дакле, можемо рећи да је једна од основних карактеристика СМС-честитки које се шаљу поводом новогодишњих и божићних празника везана за однос пошиљаоца и примаоца. Језичко обликовање ових порука директно је везано за чињеницу да оне, као подесне за слање великом броју људи, морају бити лишене сваког податка о примаоцу. С друге стране, да би их наредни пошиљалац могао дистрибуирати даље, лишене су и података о примаоцу. Тако, потпуно супротно самом смислу честитања као говорног чина, честит- 
ке које се шаљу путем нових канала комуникације, показују изузетно висок степен деперсонализованости. ${ }^{5}$

2.2. Из аспекта организације текста СМС-честитки, најдоминантније су две карактеристике: њихова дводелна структура и честа појава риме.

Највећи број порука обликован је тако да се јасно разграничавају два сегмента. Први део поруке чини општи део у којем се говори о празнику који је повод слања поруке, обичајима везаним за њега или вредностима које се с њим повезују. Други део поруке садржи исказ којим се празник честита, као у следећим примерима:

U zidine Hilendara rodila se vera stara, rodila se jos od Hrista ja je volim jer je čista, ta vremena behu davna Srećna vam nova godina pravoslavna

Svaki trenutak u danu ima svoju vrednost. Jutro donosi NADU, poslepodne VERU, veče LJUBAV, a noć ODMOR. Nadam se da ćeš u svakom ovom trenutku uživati svakoga dana u 2016. SREĆNA TI NOVA

Римом, и то углавном парном, одликује се чак око две трећине порука. Сасвим ретко, и финални искази којима се директно честита празник римују се са остатком поруке, као у следећем примеру:

Nocas usnite divan san s mirom slavite Badnji dan nek vam radost kroz dom tece s mirom slavite Badnje vece, nek vam srecom dom zablista na rodjendan sina HRISTA nek vas sreca kroz zivot vodi SRECAN BOZIC I HRISTOS SE RODI!

Било да се јавља као интегрални сегмент читаве поруке или да је издвојено, директно честитање најчешће се остварује у форми устаљених традиционалних образаца.

2.3. Уочава се да медиј у веома великој мери условљава и употребу писма и несловних знакова. Међутим, ове карактеристике нису идентичне онима које су забележене у свакодневној комуникацији кратким порукама.

Анализа употребе писма показује да је латиница много чешће у употреби, чак и када аутор поруке истиче лексеме попут српство, православље и сл. или се позива на традиционалне вредности, као у следећем примеру:

Srpski mislim, srpski pišem, srpski zborim, srpski dišem, srpsku crkvu obilazim, moje milo srpstvo pazim, za njega se Bogu molim, pravoslavlje sveto volim, i krstim se sa tri prsta, tradicija to je srpska, i dičim se jer ja imam srpsko srce u grudima, pa ću noćas kao i ti srpsku novu proslaviti. U to ime imam želju da je čekaš u veselju, u radosti i ljubavi, ukućani da su zdravi, svaka sreća da vas prati, da se dobro dobrim vrati !

Може се претпоставити да је један од узрока далеко чешће употребе латинице и ограничење у броју карактера: порука писана ћириличним словима лимитирана је на 70 карактера уместо стандардних 160.

\footnotetext{
${ }^{5}$ Иако се у овом раду не бавимо честитањем празника путем друштвених мрежа, треба напоменути да и тај тип честитки у овом смислу показује исте карактеристике. Један корисник друштвене мреже Фејсбук објавио је у јануару 2016. године следећу поруку као реакцију на овај тренд: „Мрзело ме је да куцам поруку нову да бих ти честитао годину нову, ходам улицом а напољу је зима, па сам само кликнуо на ПОШАљИ СВИМА. Ако не можеш сам да напишеш пар слова, нека и теби буде срећна Година нова. Кад те сретнем негде отрешћу те ко слину, носи се у лепу ..."
} 
Међутим, латинично писмо у оваквим порукама знатно се ређе употребљава без дијакритичких знака у односу на свакодневне поруке, а није забележена ни употреба латинице у комбинацији са графемама енглеске абецеде, што је „опште место онлајн комуникације” (Јањић/Чутура 2012:141). Ово је свакако појава узрокована значајем празника и самог чина честитања.

Честа је употреба несловних знакова који на веома брз, ефикасан и економичан начин обављају функцију додатне илустрације или допуњавања емоционалног плана поруке. То су најчешће срце, астериск који означава, у корелацији са текстом, пахуљу или звезду, плус који означава крст, као у следећим примерима:

\footnotetext{
*СВЕ*ТЕ*МАЛЕ*ПАХУЉЕ*БЕЛЕ**ТО*СУ*МОЈЕ*ИСКРЕНЕ*ЖЕЉЕ*! *ЈА*НЕ МАМ*ТОЛИКО*СЛОВА**НЕК*ТИ*ЈЕ*СРЕЋНА*ГОДИНА*НОВА***!!!

Jedna * za tvoj slatki osmeh ,dve ** za te tvoje iskrice u ocima. Ma sta nabrajam neka ti se sve zvezde sa neba skupe na dlan i ulepsaju ti Badnji dan.;-) Neka bude ljubavi i zdravlja, u tvome domu večitoga slavlja... Nek se pije vino i rakija i pogača peče, i neka vam je srećno ovo BADNJE VEČE..

+++ Док се бадњаци весело ложе, нек' ти се радост и срећа множе, нек' весеље свуда блиста за рођендан Бога Христа, нек се пуца из пушака због душмана и турака, нек продане виде главе како СРБИ БОЖИЋ СЛАВЕ! +++
}

2.4. Синтаксичка структура СМС-честитки веома је једноставна. Анализиране поруке већином чине независносложене реченице у којима су предикатске реченице углавном у саставном односу. Најчешће су повезане запетом a ређе везником, с тим да је апсолутно доминантан везник $u$.

Било да је порука оформљена као једна независносложена реченица или као низ комуникативних реченица, њихов је однос у највећем броју случајева сводив на исти модел: низање кратких предикатских реченица истосмерног смисла, на пример:

Бадњак се ложи, / ватра се пламти, / здравље и срећа нек' вас прати, / и нек' свако ново сутра буде радост новог јутра, / и срећан вам Божић сутра! / Христос се роди!!!

Neka te zdravlje služi. / Ljubav da daješ i primaš, / para uvek da imaš, / sreća neka te prati... / Ja ti poželeh, / a Bog će ti dati... / Srećan BADNJI DAN!!!

Neka ti sreća postane stvarnost, / neka ti zdravlje postane trajnost, / neka te ljubav u srcu greje / i neka se ostvare sve tvoje želje. / Srećna Nova godina !

И на синтагматском нивоу јасно се издваја управо овај семантички однос, а готово редовно је реч о набрајању жеља:

Драги пријатељу!!! Желим ти: сибирско здравље, јеврејско богатство, француску љубав, циганску секирацију, а све остало има код кинеза! Срећна 2016.

Želim ti okeane zdravlja, mora sreće i ljubavi, jezera uspeha, reke novca - i nijednu kap tuge i bola.

Једини типови зависних клауза који се не јављају по изузетку јесу изричне и, углавном у уводним сегментима, као одредница празничног тренутка, временске, што илуструјемо следећим примерима: 
+++ Док се бадњаци весело ложе, / нек’ ти се радост и срећа множе, / нек' весеље свуда блиста за рођендан Бога Христа, / нек се пуца из пушака због душмана и турака, / нек продане виде главе / како СРБИ БОЖИЋ СЛАВЕ! +++

Казаљке када се склопе у пола ноћи, руке ти пружити нећу моћи и зато користим ову прилику да ти честитам ГОДИНУ НОВУ. За дане боље, за дане нове, за све што се срећом зове, за радост и лепоту, за све најлепше у животу.

Kad Bozic pokuca na vrata i spoje se kazaljke sata, neka ti se ispune sve zelje, tugu nek otera veselje. Sretno Badnje Vece

Dok badnjaci gore evo nama badnje vece!!! Nek vam bog podari puno srece, ljubavi,i puno prijateljstva. Sretno vam badnje vece!

А док се неко за тебе моли, ти срећу пожели, праштај и воли. Мир Божији, Христос се роди!

Док честитку читаш ову и годину чекаш нову, из мог срца прими жељу, дочекај је у весељу! Нека ти је живот пун среће и снова, нека ти је срећна ГОДИНА НОВА!!! Цмок

У великом броју порука присутна је елипса глагола желети који се у овом виду комуникације подразумева, а ретки су случајеви у којима је глагол желети ипак присутан. Једном се јавља глагол пожелети:

Ако је пахуља срећа - желим ти планину белу! Ако је љубав кап воде - желим ти реку целу! Ако је успех звезда - желим ти небески свод!

Neka te zdravlje služi. / Ljubav da daješ i primaš, / para uvek da imaš, / sreća neka te prati... / Ja ti poželeh, / a Bog će ti dati... / Srećan BADNJI DAN!!!

Најчешћи модел формуле директног честитања у новогодишњим честиткама јесте „Срећна ти / Срећна”. У божићним честиткама (послатим на Божић, Бадњи дан или Бадње вече) најбројније су реченице са партикулом нек(a), заступљене и у новогодишњим честиткама. ${ }^{6}$ „Модел по коме се остварују ове конструкције записује се као Neka + N3 + (cop. + leks.) - Нека + датив + именски предикат (je + прилог или прилошки израз). Реципијентни датив може и да изостане и онда жеља има опште значење - односи се на ширу групу, све присутне (Нека је са срећом!). Дативом може бити означено било које лице (ти, му, вам, им), па и говорно (Е па нека ми је на здравље!)” (Бабић 2010: 193). У нашем корпусу приметно је да новогодишње поруке чешће од божићних садрже реципијентни датив.

Бадњак се ложи, ватра се пламти, здравље и срећа нек' вас прати, и нек' свако ново сутра буде радост новог јутра, и срећан вам Божић сутра! Христос се роди!!!

Neka ovaj Badnji Dan bude Vama radostan, puno zdravlja, puno sreće uz krst časni i uz sveće, nek se čuje pesme glas, blagoslovi Bože nas! SRETNO TI BADNJE VEČE!

Neka bude ljubavi i zdravlja, u tvome domu večitoga slavlja... Nek se pije vino i rakija i pogača peče, i neka vam je srećno ovo BADNJE VEČE..

Neka te zdravlje služi. Ljubav da daješ i primaš, para uvek da imaš, sreća neka te prati... Ja ti poželeh a Bog će ti dati... Srećan BADNJI DAN!!!

\footnotetext{
${ }^{6}$ Ова партикула, уз тако, тешко, дабогда и благо спада у групу конвенционално-афективних партикула. Оне су „по функцији врло блиске јер се употребљавају у строго конвенционализованим говорним чиновима који се сврставају у тзв. експресиве - којима говорник изражава свој став о нечему (жаљење, проклињање, благосиљање и сл.) и комисиве - којима се говорник обавезује на одређене поступке (заклињање). А издвајају се на основу одређених специфичности у вези са њиховим укључењем у структуру исказа које упућују на постојање извјесних синтаксичких релација, иначе несвојствених партикулама" (Бабић 2010: 181).
} 
Koliko iglica ima bor, koliko prozora ima dvor, koliko zvezda nebom šeće toliko ljubavi i sreće nek celoj porodici donese Badnje veče!

Нек ти живот буде као најсјајнија звезда, у коме за тугу никад нема места, нека јава буде остварење снова, СРЕЋНА ТИ ГОДИНА НОВА!

Neka sva sreća sveta pripadne tebi, neka ti ljubav bude uzvraćena u istoj meri, neka sve što je lepo bude tvoje, to iskreno želi srce moje. Srećna Nova Godina!

Neka ti sreća postane stvarnost, neka ti zdravlje postane trajnost, neka te ljubav u srcu greje i neka se ostvare sve tvoje želje. Srećna Nova godina !

Neka ti 2016-ta donese sve što zaslužuješ i neka ti se ostvari sve što poželiš. Puno sreće u novoj 2016-toj.

Чест је и модел са да, с тим да је, како смо већ нагласили, најчешће елидиран управни глагол:

Da se oblačiš po poslednjoj modi, Da ti viski uvek godi, Da se brčkaš u đakuzi vodi, Da izgledaš kao bilder-bodi, Na loto 7 ubodi, MIR BOŽJI, HRISTOS SE RODI!

О синтаксичким карактеристикама СМС-честитки можемо закључити да су прилично сведене и једнообразне. Сличне карактеристике одликују и комуникацију путем друштвених мрежа, тако да можемо рећи да, у синтаксичком погледу, ова два типа комуникације представљају исту врсту кратких порука: „уколико анализирамо изузетно сиромашну структуру и семантику њихових исказа, ${ }^{7}$ стиче се утисак да овакав стил изражавања неповољно утиче на језичку културу. Као да се враћамо праисторијском протојезику који не служи за исказивање сложених мисли. Или као да је једини циљ комуникације давање једноставних информација, површно обавештавање о емотивном стању или најава догађаја, а не расуђивање, полемика, анализа и синтеза стварности” (Ашић 2014: 95). Приметне су „симплификоване, често крње и недовршене реченичне структуре, стихијски искази" (Јањић/Чутура 2012: 147). Ове карактеристике свакако су присутне и у свакодневним СМС- порукама, али, ипак, додатна пажња са којом се обликују честитке поводом великих празника као резултат даје другачију синтаксичку слику. Она јесте једноставна, структура реченице је најчешће „низање” независних реченица, али је далеко од „стихијске синтаксе” која је приметна у свакодневној размени порука.

\section{3. Закључак}

На основу спроведеног истраживања можемо закључити да је слање циркуларних СМС-порука постало саставни део божићних и новогодишњих празника. Овакве честитке показују значајне диференцијалне црте и у односу на свакодневну комуникацију путем СМС-порука и у односу на устаљену форму и структуру говорног чина честитања.

Анализиране поруке пре свега се одликују деперсонализацијом, односно изостанком упућивања на пошиљаоца и примаоца. Додатно, енкодер и по-

\footnotetext{
${ }^{7}$ Мисли се на кориснике Фејсбук мреже.
} 
шиљалац у великом броју случајева нису иста особа. Структура ових порука углавном је дводелна и састоји се од општег дела који се односи на празник и исказа којим се празник честита. Доминира латинично писмо, али, у односу на свакодневну CMC-комуникацију, често са присутним дијакритичким знацима и без графема енглеске абецеде. Уколико су присутни, несловни знаци имају посебну функцију, а њихов избор је веома сужен.

У погледу синтаксичких карактеристика, издвајају се две доминантне црте: напоредне синтагме и предикатске реченице у саставном односу и устаљене формуле директног честитања.

Као један од говорних чинова који се односе на саговорника, честитање спада у конвенције учтивости, искази који се при том користе „су углавном клишеи, а ситуације у којима се користе подлежу устаљеним друштвеним конвенцијама" (Мразовић 2009: 676). Међутим, како смо у овом сегменту рада видели, увелико су се усталили потпуно нови клишеи и конвенције. Та промена догодила се тако брзо да су карактеристике нових модела честитања празника у стручној литератури говото потпуно неиспитане.

Иако је појава оваквих честитки релативно „млада”, поруке (честитке) које су послужиле као материјал за истраживање у овом раду показују низ истих особина, што потврђује да су њихове карактеристике већ до те мере устаљене да слободно можемо говорити о чврстим обрасцима.

\section{ЛИТЕРАТУРА}

Ашић 2014: Тијана Ашић, „Прекључивање и мешање кодова у свакодневном разговору у српском језику и његове синтаксичке, семантичке и прагматичке импликације: комуникација на друштвеној мрежи Фејсбук”, $\mathrm{Ha}$ учни састанак слависта у Вукове дане, 43/1, 85-97.

Бабић 2010: Миланка Бабић, Огледи из прагматичке синтаксе, Источно Сарајево: Универзитет у Источном Сарајеву, Филозофски факултет Пале.

Јањић 2014: Марина Јањић, „Језички конфликт у Свету компјутера”, Научни састанак слависта у Вукове дане, 43/1, 149-162.

Јањић/Чутура 2012: Марина Јањић, Илијана Чутура, Простор, време, друштво - сусрети у језику, Јагодина: Факултет педагошких наука.

Кристал 2001: David Crystal, Language and the Internet, Cambridge: Cambridge University Press.

Кристал 2008: David Crystal, Txtng The Gr8 Db8, Oxford University Press.

Мразовић 2009: П. Мразовић, Граматика српског језика за страние, Нови Сад: Издавачка књижарница Зорана Стојановића

Прћић 2011: Твртко Прћић, Енглески у српском, Нови Сад: Филозофски факултет.

Радић-Бојанић 2007: Б. Радић-Бојанић, Neko za chat? Дискурс електронских ћаскаоница на енглеском и српском језику, Нови Сад: Филозофски факултет, Футура публикације. 
Ристић 1999: Стана Ристић, „Илокуцијски аспекти употребе партикула”, у: С. Ристић, М. Радић-Дугоњић, Реч. Смисао. Сазнање (студије из лексичке семантике), Београд: Филолошки факултет Универзитета у Београду, $117-127$.

Сегештад 2005: Ylva Hård Segerstad, "Language in SMS - a socio-linguistic view", y: Harper, R., Palen, L., Taylor, A. (Eds.), The Inside Text. Social, Cultural and Design Perspectives on SMS, Dordrecht: Springer, 33-51.

Тошовић 2002: Бранко Тошовић, Функционални стилови, Грац: Институт за славистику Универзитета Карл-Франц.

Шипка 2008: Милан Шипка, Култура говора, Нови Сад: Прометеј.

Ilijana Čutura

\section{INFLUENCE OF GLOBALIZATION ON THE COMMUNICATIVE DISCOURSE OF CONGRATULATING}

Summary

The main research topics of this paper are the status of the forms of congratulations sent as short text messages and analyse of their textual and linguistic features. The changes, when compared to traditional congratulating, include text organization and typical syntactic features. Main innovations are based on the fact that the relation between message sender and message recipient is changed so that it does not include personal relation any more.

Key words: sms messages, congratulating, depersonalization, sender, recipient. 